\title{
EFISIENSI PENGGUNAAN FAKTOR PRODUKSI TENAGA KERJA DAN MODAL PADA USAHATANI KEDELAI DI KELURAHAN PAMONA KECAMATAN PAMONA PUSELEMBA KABUPATEN POSO
}

\author{
The Using Efficiency of Labor and Capital Production Factors in Soybean Farming at \\ Pamona Village Pamona Puselemba District Poso Regency
}

\author{
Marianne Reynelda Mamondol \\ Program Studi Agribisnis Fakultas Pertanian Universitas Kristen Tentena \\ Jln. Torulemba No. 21 Tentena, Poso, Sulawesi Tengah \\ e-mail : mariannemamondol@gmail.com
}

\begin{abstract}
Abstrak
Tujuan penelitian ini ialah menganalisis efisiensi penggunaan faktor produksi tenaga kerja dan modal pada usahatani kedelai di Kelurahan Pamona Kecamatan Pamona Puselemba Kabupaten Poso dengan indikator berupa elastisitas faktor produksi, skala usaha, dan Nilai Produk Marginal (NPM). Subyek penelitian ialah 20 orang petani kedelai yang merupakan jumlah elemen populasi petani kedelai di Kelurahan Pamona. Data dikumpulkan melalui wawancara dengan subyek penelitian dan pengisian kuisioner, lalu dianalisis dengan menggunakan analisis fungsi produksi Cobb-Douglas, perhitungan skala usaha, Nilai Produk Marginal (NPM), dan rasio NPM/HFP (Harga Faktor Produksi). Hasil penelitian menunjukkan bahwa faktor produksi tenaga kerja memiliki pengaruh negatif terhadap produksi kedelai (elastisitas input -1,38956), tidak efisien atau berlebihan (rasio NPM/HFP -3,466) dan perlu dikurangi penggunaannya untuk meningkatkan produksi. Sebaliknya, faktor produksi modal memiliki pengaruh positif terhadap produksi kedelai (elastisitas input 1,00099), belum efisien (rasio NPM/HFP 2,772) dan perlu ditambah penggunaannya agar produksi dan pendapatan produsen meningkat. Usahatani kedelai berada pada skala usaha menurun (decreasing return to scale) di mana peningkatan penggunaan faktor produksi tenaga kerja dan modal secara bersamaan menyebabkan penurunan produksi kedelai. Bimbingan teknis dan bantuan kredit untuk penyediaan modal uang tunai dibutuhkan oleh petani untuk mencapai efisiensi produksi usahatani kedelai.
\end{abstract}

Kata kunci : efisiensi, faktor produksi, tenaga kerja, modal, usahatani kedelai

\begin{abstract}
The purpose of this research is to analyze the using efficiency of labor and capital production factors in soybean farming at Pamona Village Pamona Puselemba District Poso Regency with indicators of input elasticity, return to scale, and Marginal Product Value (MPV). Research subjects are 20 soybean farmers which constitutes the number of population element of soybean farmers at Pamona Village. Data is assembled through interviewing research subjects and filling up the questionairres, and then is analyzed with Cobb-Douglas production function analysis, the calculations of return to scale, Marginal Product Value (MPV), and MPV/PFP (Production Factor Price) ratio. Results indicate that labor has negative effect on soybean production (elasticity -1.38956), not efficient or overly abundant (MPV/PFP ratio -3.466) and needs to be reduced to increase production. On the contrary, capital gives positive effect on soybean production (elasticity 1.00099), has not yet efficient (MPV/PFP ratio 2.772) and should be raised so that production and producers' income could be improved. Soybean farming exists at decreasing return to scale where the increasing of both labor and capital simultaneously causes the lowering of production. Technical guidance and credit support for provisioning cash money are needed by farmers to achieve production efficiency of soybean farming.
\end{abstract}

Keywords : efficiency, production factor, labor, capital, soybean farming 


\section{PENDAHULUAN}

Kedelai merupakan jenis tanaman polongpolongan yang menjadi sumber utama protein dan minyak nabati dunia. Di Indonesia, kedelai adalah tanaman pangan strategis ketiga yang terpenting setelah tanaman padi dan jagung. Kontribusi kedelai dalam penyediaan bahan pangan bernutrisi bagi manusia sangatlah besar, sehingga kedelai disebut sebagai Gold from the Soil, terutama karena protein pada kedelai memiliki kandungan asam amino yang tinggi, seimbang, dan lengkap (Aldillah, 2015). Kandungan protein kedelai dapat mencapai $45 \%$ dan rendah kolesterol, lebih tinggi dibandingkan kandungan protein daging yang hanya sebesar $19 \%$ (Mahabirama $d k k, 2013$ ).

Masyarakat Indonesia umumnya mengonsumsi kedelai dalam bentuk produk-produk hasil olahan seperti tempe, tahu, kecap, tauco, susu kedelai, oncom, dan minyak kedelai (Isnowati, 2014). Menurut Sudaryanto $d k k$ (2001), selain sebagai sumber protein, kedelai juga memiliki kandungan lemak, mineral, dan vitamin. Dalam $100 \mathrm{~g}$ kedelai terdapat $33,3 \mathrm{~g}$ protein, $15,0 \mathrm{~g}$ lemak, $213 \mathrm{mg}$ kalsium, 9,5 mg besi, 0,65 mg vitamin B1, 0,23 mg vitamin B2, 2,8 $\mathrm{mg}$ Niacin, dan kandungan vitamin C. Di samping itu, pertumbuhan industri pakan ternak menjadikan bungkil kedelai sebagai komponen utama setelah jagung, karena kandungan proteinnya yang tinggi.

Saat ini, Indonesia termasuk salah satu negara produsen kedelai terbesar di dunia selain Amerika Serikat, Brasil, Argentina, China, dan India. Akan tetapi, produksi kedelai domestik belum dapat mencukupi kebutuhan dalam negeri yang terus mengalami peningkatan setiap tahunnya. Isnowati (2014) mengemukakan bahwa pada era tahun 1990an Indonesia pernah mengalami swasembada kedelai, di mana puncak produksi kedelai sebesar 1,8 juta ton terjadi pada tahun 1992. Saat itu produksi kedelai meningkat tiga kali lipat dibandingkan tahun 1993 saat dicanangkannya Program Bimas / Inmas Kedelai. Namun pada periode 1992 - 2011, produksi kedelai nasional menurun $3,05 \%$ per tahun, demikian pula luas panen mengalami penurunan $4,05 \%$ per tahun. Dalam beberapa tahun terakhir, luas panen kedelai secara nasional merosot dari 1.665.706 hektar (1992) menjadi 620.908 hektar (2011).

Penurunan produksi kedelai disebabkan oleh beberapa faktor, yaitu ditiadakannya penetapan kebijakan harga kedelai sejak tahun 1992, adanya kebijakan tataniaga kedelai yang dilakukan secara bebas oleh pengusaha importir, dan penetapan tarif impor jauh di bawah bound tariff pada tahun 1998 yang menyebabkan masuknya kedelai impor dengan harga murah. Sebagai akibatnya, petani kedelai dalam negeri mengalami kesulitan persaingan produknya dengan produk kedelai impor. Menurut Krisdiana (2012), kebutuhan kedelai domestik ialah sekitar 2,3 juta ton per tahun, sedangkan produksi dalam negeri hanya mampu memenuhi $30-40 \%$ dari kebutuhan nasional, sehingga kekurangannya dipenuhi dari impor.

Aimon dan Satrianto (2013) menyatakan, ketika terjadi ketidakseimbangan supply dan demand kedelai di Amerika Serikat, maka muncullah permintaan terhadap kedelai impor. Demikian pula ketika konsumsi kedelai di China melebihi produksinya, China pun melakukan impor dari negara-negara produsen kedelai seperti Argentina, Brasil, Paraguay, Uruguay, dan Bolivia. Di Indonesia, lonjakan konsumsi kedelai disebabkan meningkatnya permintaan bahan baku kedelai oleh industri pengolahan makanan skala besar, industri rumah tangga, maupun industri pakan ternak. Namun kenaikan konsumsi ini tidak diimbangi dengan kecukupan supply bahan baku. Sari $d k k$ (2013) melaporkan bahwa pada tahun 2012, produksi kedelai nasional menurun sebesar $0,96 \%$, sebaliknya konsumsi kedelai meningkat sebesar 3,82 \%, dan hal ini menyebabkan peningkatan impor kedelai sebesar 5,76\%. Hal ini menunjukkan bahwa peningkatan konsumsi kedelai tidak diimbangi oleh gairah petani dalam melakukan budidaya tanaman kedelai. Menurut Aldillah (2015), masih rendahnya tingkat produktivitas dan keuntungan usahatani kedelai dibandingkan komoditas lainnya seperti padi dan jagung mengakibatkan petani kurang berminat menanam kedelai dan memilih mengusahakan tanaman lain yang lebih menguntungkan, sehingga luas areal tanam dan produktivitas cenderung mengalami penurunan. Daya saing kedelai terhadap komoditas pangan lainnya memang lebih lemah, demikian pula daya saing kedelai domestik terhadap kedelai impor (Mutiara $d k k, 2013$ ).

Kabupaten Poso merupakan salah satu penghasil komoditas kedelai di Provinsi Sulawesi Tengah. Data mengenai luas panen, produksi, dan produktivitas kedelai Kabupaten Poso untuk tahun 2012 - 2015 dapat dilihat pada tabel sebagai berikut. 
Tabel 1. Luas panen, produksi, dan produktivitas kedelai Kabupaten Poso

\begin{tabular}{rrrrrrr}
\hline Tahun & $\begin{array}{c}\text { Luas } \\
\text { Panen } \\
\text { (ha) }\end{array}$ & $\begin{array}{c}\text { Pertumbuhan } \\
(\%)\end{array}$ & $\begin{array}{c}\text { Produksi } \\
\text { (ton) }\end{array}$ & $\begin{array}{c}\text { Pertumbuhan } \\
(\%)\end{array}$ & $\begin{array}{c}\text { Produkticitas } \\
\text { (kw/ha) }\end{array}$ & $\begin{array}{c}\text { Pertumbuhan } \\
(\%)\end{array}$ \\
\hline 2012 & 178 & - & 202 & - & 11,35 & - \\
2013 & 182 & 2,247 & 214 & 5,941 & 11,76 & 3,612 \\
2014 & 280 & 53,846 & 323 & 50,935 & 11,54 & $-1,871$ \\
2015 & 280 & 0,000 & 471 & 45,820 & 16,82 & 45,754 \\
\hline
\end{tabular}

Sumber : BPS Sulawesi Tengah

Data pada tabel menunjukkan bahwa kedelai merupakan komoditas yang cukup potensial untuk dikembangkan di Kabupaten Poso, terutama dikarenakan adanya trend peningkatan pertumbuhan luas panen, produksi, dan produktivitas kedelai dari tahun 2012 hingga 2015. Beberapa kecamatan penghasil utama kedelai untuk Kabupaten Poso ialah Poso Pesisir Selatan, Pamona Utara, Pamona Tenggara, Lore Peore, dan Poso Pesisir Utara (BPS Poso, 2016). Sementara itu, pengusahaan kedelai di Kecamatan Pamona Puselemba, khususnya di Kelurahan Pamona masih sangat terbatas karena umumnya petani cenderung mengusahakan tanaman pangan seperti padi dan jagung yang nilai ekonominya relatif lebih tinggi. Padahal di Kecamatan Pamona Puselemba terdapat beberapa industri rumah tangga yang memproduksi tahu dan tempe dan memerlukan kedelai sebagai bahan bakunya. Kelompok tani kedelai di Pamona Puselemba menerima bantuan pemerintah dalam bentuk penyediaan faktor produksi benih kedelai. Pada umumnya, petani melakukan budidaya kedelai di lahan kering pada saat kuantitas curah hujan rendah.

Survei pendahuluan memperlihatkan bahwa faktor produksi berupa tenaga kerja manusia dan modal dalam bentuk uang tunai merupakan faktor produksi yang sangat dibutuhkan oleh petani dalam melakukan usahatani kedelai. Tenaga kerja manusia dibutuhkan dalam proses produksi untuk melakukan berbagai pekerjaan berupa pengolahan tanah, penanaman, pemeliharaan tanaman, panen, pasca panen, dan pemasaran hasil, di mana tenaga kerja diperoleh baik dari dalam maupun luar keluarga petani (Suratiyah, 2015). Sedangkan Hanafie (2010) menyatakan bahwa modal merupakan syarat mutlak berlangsungnya suatu usahatani. Modal usahatani diklasifikasikan sebagai bentuk kekayaan, baik berupa uang maupun barang yang digunakan untuk menghasilkan sesuatu secara langsung atau tidak langsung dalam suatu proses produksi. Pembentukan modal bertujuan untuk meningkatkan produksi dan pendapatan usahatani, serta menunjang pembentukan modal lebih lanjut.
Hasil penelitian Isnowati (2014) menunjukkan bahwa faktor modal dan tenaga kerja tidak berpengaruh secara signifikan terhadap produksi kedelai di Desa Kebonagung Kecamatan Tegowanu Kabupaten Grobogan, Jawa Tengah. Sementara penelitian yang dilakukan oleh Ningsih $d k k$ (2015) memperlihatkan bahwa faktor tenaga kerja memberikan pengaruh yang negatif terhadap produksi kedelai di Desa Mlorah, Kecamatan Rejoso, Kabupaten Nganjuk, Jawa Timur. Penambahan tenaga kerja justru menurunkan produksi karena rendahnya produktivitas dari tenaga kerja yang digunakan. Kurniati (2015) melaporkan bahwa secara umum kendala yang dihadapi oleh petani kedelai di Kecamatan Jawai Selatan Kabupaten Sambas, Kalimantan Barat ialah terbatasnya kemampuan manajemen dan penguasaan teknologi, sempitnya lahan, kurangnya modal, dan rendahnya produktivitas tenaga kerja. Sebaliknya hasil penelitian Widotono dan Arifin (2008) menunjukkan pengaruh positif jumlah tenaga kerja terhadap produksi kedelai di Provinsi Jawa Timur, di mana penambahan jumlah tenaga kerja menyebabkan kenaikan produksi kedelai.

Berdasarkan uraian tersebut maka perlu dilakukan penelitian untuk mengkaji penggunaan faktor produksi modal dan tenaga kerja pada usahatani kedelai di Kelurahan Pamona Kecamatan Pamona Puselemba Kabupaten Poso. Hasil penelitian ini diharapkan dapat memberikan gambaran mengenai efisiensi penggunaan faktor produksi modal dan tenaga kerja oleh petani dalam usahatani kedelai yang dilakukannya.

\section{METODE PENELITIAN}

Penelitian ini dilaksanakan pada bulan Maret hingga Mei 2016 bertempat di Kelurahan Pamona Kecamatan Pamona Puselemba Kabupaten Poso. Populasi penelitian ialah petani kedelai berjumlah 20 orang, di mana keseluruhan elemen populasi dijadikan sebagai sampel penelitian. Pengumpulan data dilakukan dengan cara wawancara terhadap subyek penelitian dan pengisian kuisioner. 
Data yang telah dikumpulkan selanjutnya dianalisis dengan menggunakan analisis fungsi produksi Cobb-Douglas untuk mengetahui faktorfaktor produksi $\left(\mathrm{X}_{\mathrm{i}}\right)$ yang berpengaruh terhadap produksi kedelai (Y). Model yang digunakan ialah :

$\mathrm{Y}=\mathrm{a} X_{1}{ }^{b_{1}} X_{2}{ }^{b_{2}} \mathrm{e}$

Untuk memudahkan pendugaan maka persamaan tersebut diubah ke dalam bentuk fungsi linear berganda sebagai berikut :

$\mathrm{Y}=\mathrm{a}+\mathrm{b}_{1} \log \mathrm{X}_{1}+\mathrm{b}_{2} \log \mathrm{X}_{2}+\mathrm{e}$

di mana :

$\mathrm{Y} \quad=$ produksi kedelai

a $\quad=$ konstanta

$\mathrm{b}_{1} \quad=$ koefisien regresi variabel $\mathrm{X}_{1}$

$\mathrm{X}_{1} \quad=$ jumlah tenaga kerja (orang)

$\mathrm{b}_{2} \quad=$ koefisien regresi variabel $\mathrm{X}_{2}$

$\mathrm{X}_{2} \quad=$ jumlah modal uang tunai $(\mathrm{Rp})$

$\mathrm{e} \quad=$ error term

Pengujian signifikansi koefisien regresi dilakukan melalui perbandingan antara nilai signifikansi hasil perhitungan dengan nilai yang ditetapkan peneliti sebesar 0,05 . Koefisien regresi signifikan apabila sig $<0,05$. Koefisien regresi pada model juga berfungsi sebagai angka elastisitas faktor produksi yang menggambarkan sensitivitas produksi sebagai akibat perubahan penggunaan faktor-faktor produksi secara fisik. Untuk menguji apakah faktor produksi tenaga kerja dan modal berpengaruh secara bersama-sama terhadap produksi kedelai digunakan uji $\mathrm{F}$ ( $\mathrm{F}$ test), dengan ketentuan bahwa nilai $\mathrm{F}$ signifikan apabila $\mathrm{F}$ hitung $<$ signifikansi 0,05. Nilai kesesuaian model (goodness of fit) yang dinyatakan dalam koefisien determinasi $\mathrm{R}^{2}$ menyatakan seberapa besar variabel dependen $(\mathrm{Y})$ dipengaruhi oleh variabel-variabel independen $\left(\mathrm{X}_{\mathrm{i}}\right)$ dalam pemodelan. Menurut Makridakis $d k k$ dalam Aldillah (2015), nilai goodness of fit yang baik ialah di atas $70 \%$ untuk aplikasi ekonomi.

Untuk mengetahui skala usaha atau Return to Scale (RTS) digunakan rumus :
RTS $=b_{1}+b_{2}$

Nilai RTS $<1$ menunjukkan skala usaha menurun (decreasing return to scale), nilai RTS = 1 menunjukkan skala usaha konstan (constant return to scale), sedangkan nilai $\mathrm{RTS}>1$ menggambarkan skala usaha meningkat (increasing return to scale).

Efisiensi penggunaan input dihitung dengan menggunakan indikator Nilai Produk Marginal (NPM). NPM merupakan nilai yang meningkatkan hasil produksi (output/Y) dari penambahan unit faktor produksi (input) $\mathrm{X}$ apabila Y dijual dengan harga tetap (Mahabirama $d k k, 2013$ ). Efisiensi tercapai apabila NPM sama dengan harga faktor produksi (Biaya Korbanan Marginal). NPM ditentukan melalui persamaan matematis :

$$
\begin{array}{ll}
\mathrm{NPM} & =\frac{\mathrm{b} \cdot \mathrm{Y} \cdot \mathrm{P}_{\mathrm{y}}}{\mathrm{X}} \\
\text { di mana } & : \\
\mathrm{NPM} & =\text { nilai produk marginal } \\
\mathrm{b} & =\text { elastisitas faktor produksi } \\
\mathrm{Y} & =\text { produksi kedelai } \\
\mathrm{Py} & =\text { harga kedelai } \\
\mathrm{X} & =\text { jumlah faktor produksi }
\end{array}
$$

Rasio NPM/Harga Faktor Produksi (HFP) > 1 menunjukkan bahwa penggunaan faktor produksi dianggap belum efisien sehingga masih dapat ditambah penggunaannya untuk memperbesar pendapatan. Rasio NPM/HFP $=1$ menunjukkan bahwa penggunaan faktor produksi efisien, sedangkan rasio NPM/HFP $<1$ menunjukkan bahwa penggunaan faktor produksi tidak efisien atau berlebihan sehingga perlu dikurangi.

\section{HASIL DAN PEMBAHASAN Pengaruh Tenaga Kerja dan Modal terhadap Produksi Kedelai}

Hasil pendugaan pengaruh faktor produksi tenaga kerja dan modal terhadap produksi kedelai diperlihatkan pada Tabel 2 sebagai berikut.

Tabel 2. Hasil pendugaan fungsi produksi Cobb-Douglas

\begin{tabular}{lrrrrl}
\hline \multicolumn{1}{c}{ Variabel } & Koefisien & Standar Error & \multicolumn{1}{c}{$\mathrm{p}$} & sig & Keterangan \\
\hline Konstanta & $-1,52676$ & 14,93326 & 0,038 & 0,050 & \\
Tenaga kerja & $-1,38956$ & 10,89476 & 0,038 & 0,050 & Signifikan \\
Modal & 1,00099 & 0,00023 & 0,001 & 0,050 & Signifikan \\
& & & & & \\
\hline $\mathrm{R}^{2}=90,12 \%$ & & & & & \\
F val. $=0,000$ & & & & & \\
\hline
\end{tabular}


Hasil analisis regresi dengan menggunakan fungsi produksi Cobb-Douglas memperlihatkan nilai koefisien determinasi $\left(\mathrm{R}^{2}\right)$ sebesar $90,12 \%$ yang berarti bahwa goodness of fit antara data dengan model ialah baik, karena nilai koefisien determinasinya mendekati angka satu. Berdasarkan nilai $\mathrm{R}^{2}$ diketahui bahwa produksi kedelai dipengaruhi oleh variabel tenaga kerja dan modal sebesar 90,12\% dan sisanya sebesar 9,88\% dipengaruhi oleh variabel-variabel lain yang tidaak dimasukkan ke persamaan fungsi produksi. Hasil uji $\mathrm{F}$ menunjukkan nilai $\mathrm{F}$ hitung sebesar 0,000 yang lebih kecil dibandingkan taraf signifikansi 0,05 mengartikan bahwa faktor produksi tenaga kerja dan modal secara bersama-sama mempengaruhi produksi kedelai.

Persamaan regresi yang diperoleh melalui analisis fungsi produksi Cobb-Douglas ialah sebagai berikut :

$\mathrm{Y}=-1,52676-1,38956 \log \mathrm{X}_{1}+1,00099 \log \mathrm{X}_{2}$

Pengujian signifikansi koefisien regresi menunjukkan bahwa koefisien regresi untuk kedua variabel faktor produksi ialah signifikan pada taraf 0,05 , yang berarti bahwa kedua faktor produksi memiliki peranan yang besar dalam proses produksi kedelai di Kelurahan Pamona Kecamatan Pamona Puselemba, Poso. Variabel tenaga kerja memiliki elastisitas input $-1,38956$, di mana penggunaan tenaga kerja memberikan pengaruh yang negatif terhadap produksi kedelai. Setiap penambahan $1 \%$ tenaga kerja mengakibatkan penurunan produksi kedelai sebanyak $1,38956 \%$, sebaliknya pengurangan $1 \%$ tenaga kerja menyebabkan peningkatan produksi sebesar $1,38956 \%$. Faktor produksi modal memiliki angka elastisitas input
1,00099 , artinya terdapat pengaruh yang positif dari modal terhadap produksi kedelai. Penambahan $1 \%$ modal menyebabkan peningkatan produksi 1,00099 $\%$, sebaliknya jika modal berkurang $1 \%$ maka produksi kedelai mengalami penurunan 1,00099\%.

Untuk mengetahui skala usaha dari kegiatan usahatani kedelai di Kelurahan Pamona maka koefisien regresi $b_{1}$ dan $b_{2}$ dijumlahkan sehingga diperoleh angka - 0,38857. Angka ini mengindikasikan skala usaha menurun (decreasing return to scale), di mana tambahan output lebih kecil daripada tambahan input. Jadi apabila penggunaan faktor produksi tenaga kerja dan modal ditingkatkan bersama-sama secara proporsional sebesar $1 \%$ maka produksi kedelai akan menurun sebesar $0,38857 \%$. Sebaliknya jika kedua faktor produksi dikurangi sebesar $1 \%$ secara bersamasama maka produksi kedelai meningkat sebesar $0,38857 \%$.

\section{Analisis Efisiensi Usahatani Kedelai}

Efisiensi ekonomi usahatani kedelai di Kelurahan Pamona dapat diketahui melalui rasio NPM dengan Harga Faktor Produksi (HFP) atau Biaya Korbanan Marginal (BKM). Efisiensi ekonomi tercapai apabila nilai rasio NPM-HFP sama dengan satu, yang berarti bahwa penggunaan faktor-faktor produksi mencapai tingkat yang optimal dan produsen memperoleh keuntungan yang maksimum. Analisis efisiensi diperlukan untuk membantu petani mengalokasikan penggunaan faktor-faktor produksi untuk menghindari pemborosan (Rahayu dan Riptanti, 2010). Hasil analisis efisiensi diperlihatkan pada Tabel 3 sebagai berikut.

Tabel 3. Analisis efisiensi dan faktor produksi optimal pada usahatani kedelai

\begin{tabular}{lrrrrrr}
\hline $\begin{array}{c}\text { Faktor } \\
\text { produksi }\end{array}$ & $\begin{array}{c}\text { Rata-rata } \\
\text { penggunaan } \\
\text { faktor } \\
\text { produksi }\end{array}$ & Koefisien & NPM & HFP & NPM/HFP & $\begin{array}{c}\text { Faktor } \\
\text { produksi } \\
\text { optimal }\end{array}$ \\
\hline $\begin{array}{l}\text { Tenaga } \\
\text { Kerja }\end{array}$ & 7,35 & $-1,38956$ & $-172.305,44$ & 50.000 & $-3,446$ & $-25,328$ \\
Modal & $329.076,00$ & 1,00099 & $912.302,29$ & 329.076 & 2,772 & $912.198,672$ \\
\hline
\end{tabular}

Tabel 3 memperlihatkan bahwa rasio NPM/HFP pada variabel tenaga kerja ialah $-3,446$ atau memiliki nilai yang lebih kecil dari 1 . Artinya ialah bahwa penggunaan faktor produksi tenaga kerja tidak efisien atau berlebihan sehingga perlu dikurangi. Rasio NPM/HFP sebesar $-3,446$ berarti bahwa setiap penambahan tenaga kerja sebesar 1 orang akan menyebabkan penurunan penerimaan sebesar Rp 172.305,44 dan biaya tambahan sebesar Rp 50.000,00. Biaya yang dikeluarkan lebih besar 
dan tidak akan memperoleh pendapatan akibat penerimaan yang bernilai negatif. Nilai faktor produksi optimal sebesar -25,328 menunjukkan bahwa penggunaan faktor produksi tenaga kerja memiliki nilai yang lebih kecil daripada 0 , oleh karena itu maka penggunaan tenaga kerja perlu dikurangi. Pada umumnya petani hanya mengusahakan lahan kedelai rata-rata seluas 20 are, sehingga penggunaan tenaga kerja luar keluarga akan menyebabkan tambahan biaya tunai berupa upah tenaga kerja. Oleh karena itu petani dapat mengefektifkan penggunaan tenaga kerja yang berasal dari dalam keluarga petani sendiri guna mengurangi pembayaran upah tenaga kerja. Apabila dikaitkan dengan nilai skala usaha (return to scale) yang negatif, tambahan jumlah tenaga kerja akan menyebabkan inefisiensi karena lebih besar dibandingkan nilai tambahan produksi yang diperoleh.

Dari Tabel 3 dapat diketahui pula bahwa rasio NPM/HFP untuk variabel modal ialah 2,772 atau bernilai lebih besar dari 1 . Nilai ini mengindikasikan bahwa penggunaan faktor produksi belum efisien atau masih kurang dan perlu ditambahkan. Rasio NPM/HFP sebesar 2,772 menunjukkan bahwa setiap penambahan modal sebesar $\mathrm{Rp} 1$ akan menyebabkan peningkatan penerimaan sebesar Rp 912.302,29 dan tambahan biaya yang dikeluarkan sebesar Rp 329.076,00. Tambahan penerimaan jauh lebih besar daripada tambahan biaya yang dikeluarkan, sehingga penambahan modal akan menyebabkan tambahan pendapatan petani menjadi lebih besar. Nilai faktor produksi optimal untuk modal sebesar $\mathrm{Rp}$ 912.198,672 berarti bahwa produksi kedelai akan mencapai optimal apabila petani menggunakan modal uang tunai sebesar Rp 912.198,672 atau 2,772 kali lebih besar daripada modal rata-rata yang digunakan dalam proses usahatani.

Tambahan modal usaha memang diperlukan oleh petani untuk meningkatkan produksi, sebab modal uang tunai yang dimiliki digunakan petani untuk membeli pupuk dan pestisida, membayar upah tenaga kerja luar keluarga, melakukan proses pasca panen berupa perontokan dengan menyewa mesin perontok, dan melakukan proses pemasaran. Kekurangan modal uang tunai menyebabkan petani tidak dapat melakukan kegiatan budidaya kedelai secara optimal, sebagai contoh ada petani yang tidak melakukan pemupukan pada tanaman sehingga hasil panen tidak maksimal. Hal ini sejalan dengan hasil penelitian Tahir $d k k$ (2010) yang menyatakan bahwa kekurangan modal pada petani kedelai di Sulawesi Selatan mengakibatkan petani kedelai menunda waktu pemberian pupuk, memberi pupuk di bawah dosis yang direkomendasikan, atau bahkan tidak melakukan pemupukan sama sekali. Produksi kedelai di Kelurahan Pamona pada tahun 2015 ialah rata-rata sebesar $151,9 \mathrm{~kg}$ pada areal dengan luasan rata-rata 20 are, sehingga produktivitasnya hanya mencapai $0,3038 \mathrm{kw} / \mathrm{ha}$, jauh di bawah produktivitas kedelai Kabupaten Poso sebesar 16,82 kw/ha (2015). Diduga hal ini berkaitan dengan belum optimalnya penerapan teknik budidaya kedelai oleh petani. Sudaryanto $d k k$ (2001) mengemukakan bahwa tingkat penerapan teknologi oleh petani dibatasi oleh beberapa hal seperti keterbatasan penggunaan tenaga kerja, tingkat pengetahuan dan kemauan petani, serta keterbatasan modal. Karena itu peningkatan efisiensi produksi kedelai dapat ditempuh melalui pemberian bantuan teknis budidaya dan bantuan kredit sebagai insentif berproduksi bagi petani.

\section{KESIMPULAN DAN IMPLIKASI KEBIJAKAN \\ Kesimpulan}

Faktor produksi tenaga kerja dan modal berpengaruh secara signifikan pada produksi kedelai di Kelurahan Pamona Kecamatan Pamona Puselemba Kabupaten Poso. Faktor produksi tenaga kerja berpengaruh negatif terhadap produksi kedelai, penggunaannya tidak efisien atau berlebihan, sehingga perlu dikurangi agar pendapatan petani meningkat. Faktor produksi modal berpengaruh positif terhadap produksi kedelai, penggunaannya belum efisien atau masih harus ditambahkan untuk memaksimumkan pendapatan petani sebagai produsen kedelai. Penggunaan faktor produksi tenaga kerja dan modal secara bersama-sama secara proporsional menyebabkan skala usaha menurun (decreasing return to scale), di mana peningkatan penggunaan kedua faktor produksi secara bersamaan menyebabkan penurunan pada produksi kedelai.

\section{Implikasi Kebijakan}

Upaya peningkatan efisiensi produksi kedelai di Kelurahan Pamona Kecamatan Pamona Puselemba Kabupaten Poso dapat dilakukan melalui kegiatan penyuluhan dan pendampingan secara berkesinambungan terhadap petani, agar petani dapat melaksanakan teknik budidaya kedelai dengan baik guna meningkatkan produksi. Diperlukan pula penguatan sistem kelembagaan berupa jaminan akses pasar bagi produk kedelai yang dihasilkan, harga produk yang 
menguntungkan, serta bantuan kredit untuk penyediaan modal uang tunai bagi petani kedelai.

\section{REFERENSI}

Aimon, H. dan A. Satrianto, 2013. Prospek Konsumsi dan Impor Kedelai di Indonesia Tahun 2015 - 2020. Jurnal Kajian Ekonomi. $3(5): 1-13$.

Aldillah, R., 2015. Proyeksi Produksi dan Konsumsi Kedelai Indonesia. Jurnal Ekonomi Kuantitatif Terapan. 8 (1):9-23.

BPS Poso, 2016. Kabupaten Poso dalam Angka 2015. Badan Pusat Statistik. Poso.

BPS Sulteng, 2013. Sulawesi Tengah dalam Angka 2012. Badan Pusat Statistik. Palu.

BPS Sulteng, 2014. Sulawesi Tengah dalam Angka 2013. Badan Pusat Statistik. Palu.

BPS Sulteng, 2015. Sulawesi Tengah dalam Angka 2014. Badan Pusat Statistik. Palu.

BPS Sulteng, 2016. Sulawesi Tengah dalam Angka 2015. Badan Pusat Statistik. Palu.

Hanafie, R., 2010. Pengantar Ekonomi Pertanian. Penerbit Andi. Yogyakarta.

Isnowati, S., 2014. Faktor Yang Mempengaruhi Produksi Kedelai di Desa Kebonagung Kecamatan Tegowanu Kabupaten Grobogan. Jurnal SEPA. 10 (2) : 177 - 185.

Krisdiana, R., 2012. Daya Saing dan Faktor Determinan Usahatani Kedelai di Lahan Sawah. Jurnal Penelitian Pertanian Tanaman Pangan. 31 (1) : 6- 12.

Kurniati, D., 2015. Perilaku Petani Terhadap Risiko Usahatani Kedelai di Kecamatan Jawai Selatan Kabupaten Sambas. Jurnal Social Economic of Agriculture. 4 (1) : 32 - 36.
Mahabirama, A.K., H. Kuswanti, S. Daryanto, dan R. Winandi, 2013. Analisis Efisiensi dan Pendapatan Usahatani Kedelai di Kabupaten Garut Provinsi Jawa Barat. Jurnal Aplikasi Manajemen. 11 (2) : $197-206$.

Mutiara, F., D. Koestiono, dan A.W. Muhaimin, 2013. Keunggulan Komparatif dan Dampak Kebijakan Subsidi Input Terhadap Pengembangan Komoditas Kedelai (Glycine max) di Kabupaten Pasuruan. Jurnal Habitat. $14(2): 92-102$.

Ningsih, I.M, R. Dwiastuti, dan Suhartini, 2015. Determinan Efisiensi Teknis Usahatani Kedelai. Jurnal Manajemen dan Agribisnis. $12(3): 216-225$.

Rahayu, W. dan E.W. Riptanti, 2010. Analisis Efisiensi EkonomiPenggunaan Faktor-faktor Produksi pada Usahatani Kedelai di Kabupaten Sukoharjo. Jurnal Caraka Tani. 25 (1) : 119 -125 .

Sari, P.M., H. Aimon, dan E. Syofyan, 2013. Analisis Faktor-faktor yang Mempengaruhi Produksi, Konsumsi, dan Impor Kedelai di Indonesia. Jurnal Kajian Ekonomi. 3 (5) : 14 -41 .

Sudaryanto, T., I.W. Rusastra, dan Saptana, 2001. Perspektif Pengembangan Ekonomi Kedelai di Indonesia. Jurnal FAE. 19 (1) : 1-20.

Suratiyah, K., 2015. Ilmu Usahatani. Penebar Swadaya. Jakarta.

Tahir, A.G., D.H. Darwanto, J.H. Mulyo, dan Jamhari, 2010. Analisis Efisiensi Produksi Sistem Usahatani Kedelai di Sulawesi Selatan. Jurnal Agro Ekonomi. 28 (2) : 133 - 151.

Widotono, H. dan M.Z. Arifin, 2008. Upaya Peningkatan Produksi Kedelai (Glycine max Merr.) Sebagai Upaya Meningkatkan Keuntungan Petani di Jawa Timur. Jurnal Sosial Ekonomi Pertanian. 2 (1) : 38 - 47. 